\section{Pádua Fernandes}

(1971, Rio de Janeiro - RJ) é poeta, advogado e crítico literário. É Doutor em Direito (USP) e membro do Instituto de Pesquisa Direitos e Movimentos Sociais. De sua produção recente destacam-se Código negro (Cultura e barbárie, 2013), Cálcio (Hedra, 2015) e Cidadania da bomba (e-galáxia, Patuá, 2015).

E-mail: paduafernandes@gmail.com
II

Aprender a língua

quando ela, em estado terminal;

as estruturas desagregam-se,

a semântica esburacada

e a sintaxe em decomposição

comportam-se agora

como um corpo.

III

Atingida pelo complexo racista

latifúndio-farda-toga-motosserra, neste quarto,

com soro na veia,

mais uma língua agoniza;

nenhuma outra agora

pode expressar tão bem

a solidão,

o massacre,

e, confinada nesta maca de posto de saúde, o fim completo do mundo

para as estruturas

da língua. 